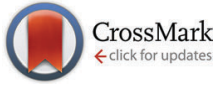

Cite this: DOI: 10.1039/c6mb00217j

\title{
The bovine milk microbiota: insights and perspectives from -omics studies
}

\author{
M. F. Addis, ${ }^{\star a}$ A. Tanca, ${ }^{a}$ S. Uzzau, ${ }^{\text {ab }}$ G. Oikonomou, ${ }^{c}$ R. C. Bicalho ${ }^{d}$ and P. Moroni ${ }^{\text {de }}$
}

Recent significant progress in culture-independent techniques, together with the parallel development of -omics technologies and data analysis capabilities, have led to a new perception of the milk microbiota as a complex microbial community with great diversity and multifaceted biological roles, living in an environment that was until recently believed to be sterile. In this review, we summarize and discuss the latest findings on the milk microbiota in dairy cows, with a focus on the role it plays in bovine physiology and health. Following an introduction on microbial communities and the importance of their study, we present an overview of the -omics methods currently available for their characterization, and outline the potential offered by a systems biology approach encompassing metatranscriptomics, metaproteomics, and metametabolomics. Then, we review the recent discoveries on the dairy cow milk microbiome enabled by the application of -omics approaches. Learning from studies in humans and in the mouse model, and after a description of the endogenous route hypothesis, we discuss the role of the milk microbiota in the physiology and health of both the mother and the offspring, and report how it can be changed by farming practices and during infection. In conclusion, we shortly outline the impact of the milk microbiota on the

Received 24th March 2016 Accepted 6th May 2016

DOI: $10.1039 / c 6 m b 00217 j$

www.rsc.org/molecularbiosystems

quality of milk and of dairy products.

\section{Microbial communities and the milk microbiota}

The complex living entities defined as microbial communities, or microbial consortia, have gained increasing interest in recent years, and the evolution of advanced molecular methods has spurred a significant wave of studies dedicated to their detailed understanding. Learning from these studies, we have now become aware that animals host a wide diversity of microbial communities that have evolved with them as a result of complex and mutualistic interactions, and that they play crucial roles in their biology and health status. ${ }^{1,2}$ The paradigm of a highly evolved, complex, and tightly host-interconnected microbial community is the gastrointestinal microbiota, ${ }^{3-6}$ but in recent years the microbial communities of diverse anatomical sites have been characterized, ranging from more obvious sites such as the skin and the genitourinary tract, to less obvious ones

\footnotetext{
${ }^{a}$ Porto Conte Ricerche, SP 55 Porto Conte/Capo Caccia, Loc. Tramariglio, 07041 Alghero, Italy. E-mail: addis@portocontericerche.it

${ }^{b}$ Università degli Studi di Sassari, Dipartimento di Scienze Biomediche, Viale S. Pietro 43/B, 07100 Sassari, Italy

${ }^{c}$ Epidemiology and Population Health, Institute of Infection and Global Health, University of Liverpool, Liverpool, UK

${ }^{d}$ Cornell University, Department of Population Medicine and Diagnostic Sciences, College of Veterinary Medicine, Ithaca, NY, 14853, USA

${ }^{e}$ Università degli Studi di Milano, Dipartimento di Medicina Veterinaria, via Celoria 10, 20133 Milan, Italy
}

such as the airways, and including areas that were previously considered to be absolutely devoid of microorganisms, such as the placenta and the fetus. ${ }^{7,8}$ Until recently, the mammary gland and the milk contained in it were also believed to be sterile, ${ }^{9}$ and microorganisms found in milk were thought to be the result of an external contamination. However, this belief has recently been challenged, as a result of the integration of culture-based methods with more sensitive molecular methods. ${ }^{10}$

Due to its importance for animal health and its correlations with the quality and safety of dairy production, the interest in understanding the origin and composition of the milk microbiota has significantly grown in the last decade. ${ }^{11}$ As a result of the rapid evolution of meta-omics sciences, a wide range of approaches is now available for its detailed characterization, enabling to gather information ranging from its taxonomic composition to its functional potential and the molecules it produces as a result of its functioning (Fig. 1).

\section{Approaches to understanding the milk microbiota: 16S metagenomics and shotgun metagenomics}

The characterization of the whole set of microbial genomes, the metagenome, might be based on target sequencing of 16S rDNA or supported by shotgun, genome wide, sequencing. The former approach relies on a combination of PCR amplification and 


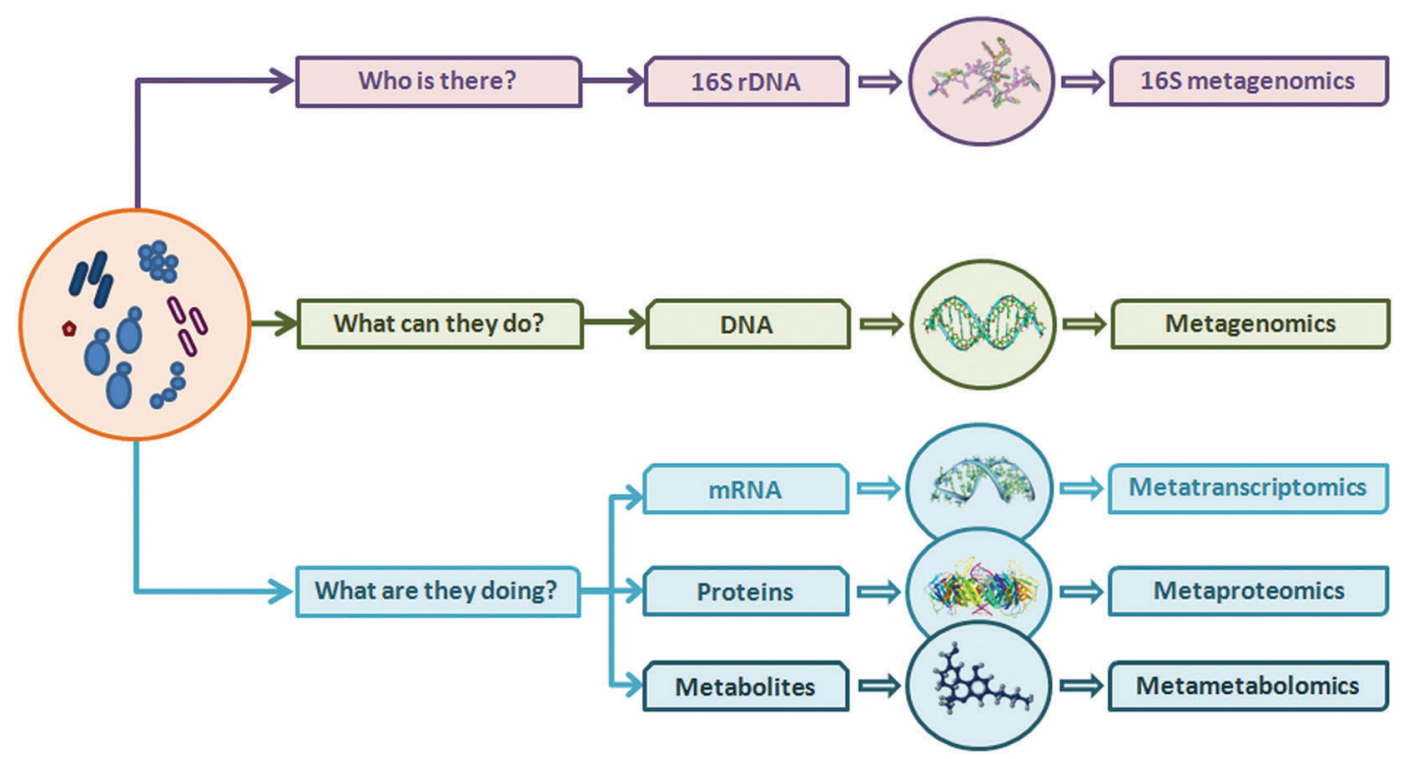

Fig. 1 Outline of the approaches available for studying the milk microbiota.

sequencing of a 16S rRNA gene fragment (16S metagenomics). ${ }^{12,13}$ Therefore, it allows the characterization of the bacterial component in the microbial community. The rRNA genes are the most conserved genes in all bacteria, yet they carry hypervariable regions, where sequences have diverged over evolutionary time. In 16S rDNA sequencing studies, a pair of so-called "universal" primers is designed to bind to conserved regions and amplify variable regions that capture the taxonomic information. Sequencing of the amplified pool of $16 \mathrm{~S}$ rDNA fragments enables the most accurate assignment of each read to its specific taxon. Then, the relative abundance of each taxon can be estimated. ${ }^{14}$

However, amplicon-based metagenomics suffers from several limitations, including the loss of diversity due to PCR biases ${ }^{15-18}$ and variability in diversity estimates. ${ }^{19}$ For instance, different 16S rDNA variable loci have differential capacity in resolution of taxa, and the number of $16 \mathrm{~S}$ rRNA gene copies in bacterial genomes varies quite considerably. In addition, amplicon sequencing gives information on the taxonomy of the community, but not on its biological functions. ${ }^{19-21}$ Although phylogenetic reconstruction may provide hints about this latter aspect, ${ }^{22}$ its accuracy is linked to the correct representation of the microbial diversity in the genome sequence databases and is hampered by the functional gene heterogeneity between strains of the same species due to horizontal gene transfer. ${ }^{23}$

To extend the information captured by $16 \mathrm{~S}$ metagenomics, shotgun metagenomics provides a further approach to study the non-culturable microbiota, offering a wider perspective on microbial diversity. ${ }^{17}$ In this case, instead of amplifying a specific target locus, the whole metagenomic DNA is extracted, reduced into fragments, and sequenced. This produces a great number of genomic sequences that align to genomic locations in all the DNA genomes of the whole community, including DNA viruses and yeasts. As a result, it becomes possible to interrogate these data either by sampling taxonomically informative loci, such as $16 \mathrm{~S}$ rDNA, or by analyzing those sequences that provide information on the functional potential of the metagenome, that is, understanding who is in the community, but also what the community is capable of doing. Interestingly, the metagenome of a complex microbial community (e.g. human feces) has been reported to be linearly correlated with the metatranscriptome, indicating that the measured potential and actual activity of the microbiota share many similarities. ${ }^{24}$

Of course, this huge potential brings several challenges. ${ }^{17,25-29}$ The first and most obvious one is represented by the extreme complexity and dimension of the data generated. Since a metagenome is a collection of genomes highly diverse in abundance, less represented genomes may be only partially sequenced, and difficulties often arise in obtaining extended sequences assembly and alignment. ${ }^{30}$ The vast amount of data generated, then, needs to be interrogated in order to obtain meaningful results. This presents problems both in terms of computational power and in terms of dedicated informatics software for analysis and interpretation of results. In addition, unwanted host DNA may be present, often in significant amounts, requiring the application of molecular and bioinformatics methods for its removal. ${ }^{31-33}$ A wide and constantly evolving range of bioinformatics tools for taxonomy and functional analysis is available in free software platforms, such as mothur, QIIME, and UniFrac for 16S, MGRAST, Kraken, and MEGAN for metagenomics, and LEfSe for differential analysis. Statistical analysis can then be carried out using software packages such as R, Metastats, or Primer-E. ${ }^{17,29,34}$

As a final consideration, generating metagenomic data is relatively more expensive than shotgun metagenomics, although the rapid progress in DNA sequencing technologies is improving this aspect. Several different platforms are available. ${ }^{35}$ Pyrosequencing with the Roche/454 GS-FLX is a reliable system that provides long reads (500 bp), but newer NGS platforms, such as Illumina HiSeq and MiSeq and Life Technologies Ion Torrent, have elevated sequencing potential. In bacterial microbiota 
studies, the HiSeq can provide the highest data output with the lowest costs, but MiSeq is preferable when short turn-around times are desired. ${ }^{36,37}$ The Ion Torrent (Ion PGM ${ }^{\mathrm{TM}}$ Sequencer and Ion Proton $^{\mathrm{TM}}$ Sequencer) is also a valid low-cost, scalable and highthroughput alternative, providing up to 400 bp sequence reads. ${ }^{38}$ To date, high-throughput sequencing has not been extensively applied to assess the ruminant milk microbiota, but that will likely change significantly in the years to come. ${ }^{11,39-41}$

\section{Beyond metagenomics: metatranscriptomics, metaproteomics, and metametabolomics methods}

As stated above, the genomic content of a microbial community gives insights into its functional potential, but no information can be inferred about the functional activities that the microbiota is actually accomplishing under a particular condition or at a particular time point. To reach this goal, additional -omics data should be collected from the microbial community by means of metatranscriptomics, metaproteomics and metametabolomics (Fig. 1 and Table 1). ${ }^{42}$

Metatranscriptomics analyzes the RNA transcript pool expressed by a microbial community at a specific point in time, ${ }^{43}$ thus allowing a simultaneous investigation of the gene expression (mRNA) and abundance (rRNA) of microorganisms. ${ }^{44}$ When 16S rDNA data are already available or not necessary, several strategies can be applied to enrich for prokaryotic mRNA molecules and reduce the rRNA fraction of metatranscriptomes, ${ }^{45}$ such as selective nuclease degradation of rRNA, ${ }^{46}$ rRNA depletion by capture using commercial kits, ${ }^{47}$ and polyadenylation and enrichment of mRNA. ${ }^{48}$ After extraction, RNA is subjected to reverse transcription to cDNA, and cDNAs are analyzed by highthroughput sequencing technologies (RNA-seq). ${ }^{49,50}$ Quality assessment and decontamination from host/rRNA sequences can be performed using standard metagenomics tools. Sample preparation issues due to the low stability of RNA and bioinformatics issues related to sequence reconstruction, annotation and statistical analysis can be considered as the main challenging aspects in a metatranscriptomics investigation. ${ }^{51}$

Metaproteomics encompasses the large-scale study of the whole protein complement of a microbiota, providing a direct measure of the functional activity of a microbial community. ${ }^{13,43}$
(Meta)proteomics approaches also enable the analysis of splicing variants and co- and post-translational modifications, as well as the detection of protein-protein interactions and protein complexes. $^{52}$ The analytical requirements for metaproteome characterization include high sensitivity and a broad dynamic range of peptide identification. ${ }^{53}$ In view of this, coupling effective liquid chromatography (LC) separation systems with high-resolution mass spectrometers (MS) represents the stateof-the-art technique for metaproteomics. ${ }^{54}$ In a typical metaproteomics experiment, the extracted proteins are therefore digested with proteolytic enzyme(s) to generate a complex peptide mixture, which is eventually analyzed by LC-MS. The presence of contaminating proteins (e.g. from the host), the huge dynamic range of protein abundance, and - even more importantly - the bioinformatics analysis issues (especially related to the construction and annotation of sequence databases for peptide identification) are the most difficult tasks in metaproteomics studies. ${ }^{55,56}$ Notably, the availability of (meta)genomic sequences from the community being studied is vital for efficient protein identification and annotation. ${ }^{57-59}$

Metametabolomics refers to the systematic analysis of the metabolite complement produced by microbial communities. Metabolites are typically in a state of flux, which implies that their abundance varies as a function of time within the ecosystem. ${ }^{60}$ The most common analytical techniques used to characterize a microbial metabolome are MS and proton nuclear magnetic resonance (NMR), each one with its respective advantages and disadvantages: NMR is a non-destructive, non-selective and costeffective approach, while MS offers better sensitivity and, if coupled to separation techniques (as LC or gas chromatography), it is capable of detecting a broader range of molecules. ${ }^{61,62}$ Specific issues concerning metametabolomics analysis are due to the non-uniformity of the molecules to be profiled (spanning a broad range of hydrophobicity and molecular weights) as well as to the impossibility to directly link the particular metabolite detected to a specific microbial taxonomy. ${ }^{51,63}$

The application of a systems biology approach - comprising metatranscriptomics, metaproteomics and metametabolomics - to the study of the milk microbiota in the years to come is expected to provide a much wider and sharper picture of the functional activity of milk microbial communities, compared to the information that one would infer from the DNA sequence alone. Each -omics technology provides a unique perspective, and, by integrating these

Table 1 Features of the -omics approaches available for studying microbial communities

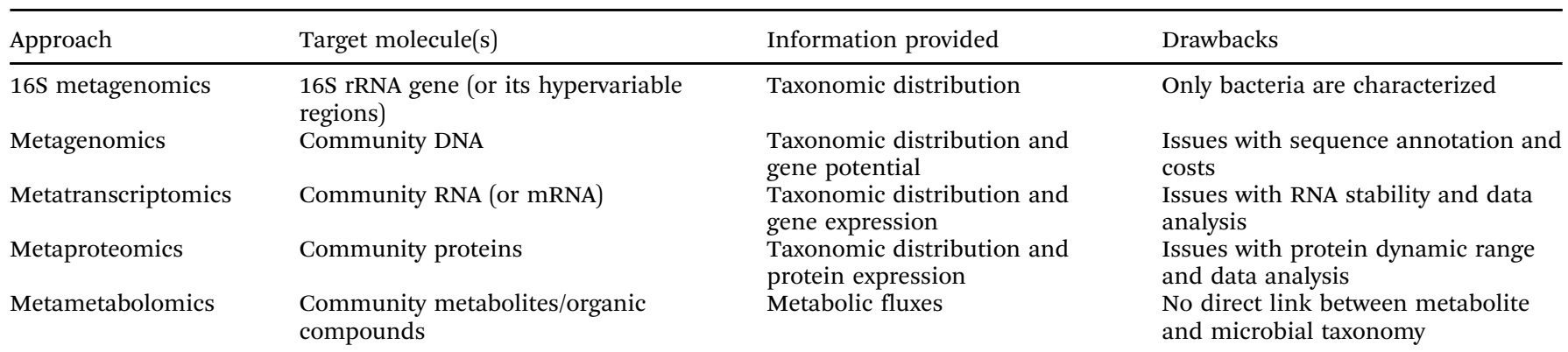


large-scale datasets, scientists can investigate microbial community dynamics and interactions at an unprecedented level (Table 1). ${ }^{64}$

\section{The healthy milk microbiota}

Milk is a complex, species-specific biological fluid aimed to satisfy the nutritional requirements of the mammalian offspring, but it also plays numerous functional roles along offspring development. ${ }^{2,65-67}$ The biological actions of milk are due to the presence of immune cells and of an assortment of active molecules, including sugars, nucleotides, lipids, immunoglobulins, antimicrobial proteins, cytokines, and other immunomodulatory factors. ${ }^{66,68-71}$ In addition, milk contains a complex and varied community of bacteria, with an abundance estimated in approximately $10^{3}-10^{4}$ colony-forming units per milliliter in human milk. ${ }^{72}$

The human milk microbiota has been the subject of different studies in recent years, aimed to understand its role in the physiology and health of both the nursing mother and her infant. ${ }^{65,66}$ On the other hand, most studies on the dairy ruminant microbiota have been carried out with focus on how the microbial flora of milk changes when it becomes a food product, either for direct consumption or for transformation into dairy products, that is, by considering the microbial ecology of raw milk, rather than how the milk microbiota behaves in the context of animal health and physiology. ${ }^{11}$ To date, only few studies have been carried out in cows with this purpose. Kuehn et al. used pyrosequencing of bacterial 16S rRNA genes to investigate bacterial DNA diversity in 10 mastitic, culture negative, milk samples. ${ }^{73}$ In this work, the microbiota of milk samples obtained from healthy quarters from the same cows was also described for comparison purposes. The authors were able to show significant differences among the microbial profiles of healthy milk samples. The most abundant genera were: Ralstonia, Pseudomonas, Sphingomonas, Stenotrophomonas, Psychrobacter, Bradyrhizobium, Corynebacterium, Pelomonas, and Staphylococcus. Abundances of Pseudomonas, Psychrobacter, and Ralstonia were significantly higher in healthy samples compared to the mastitic ones. In a more recently published study, Oikonomou et al. described in detail the microbial diversity of 144 bovine milk samples derived from clinically unaffected quarters across a range of somatic cell count values. ${ }^{74}$ Fecalibacterium, unclassified Lachnospiraceae, Propionibacterium and Aeribacillus were present in all the samples obtained from healthy quarters, and could be considered part of a healthy milk core microbiota. Other genera found to be prevalent in most of the milk samples with very low somatic cell counts were: Bacteroides, Staphylococcus, Streptococcus, Anaerococcus, Lactobacillus, Porphyromonas, Comamonas, Fusobacterium and Enterococcus (Fig. 2). Certain bacterial genera (e.g. Lactobacillus and Paenibacillus) were associated with healthier udder quarters.

Zhang et al. described the effects of different dairy cattle diets (high concentrate versus low concentrate diet) on milk microbial communities using pyrosequencing of the 16s rRNA genes. ${ }^{75}$ Despite the small number of animals enrolled in their study $(n=4)$, the authors were able to suggest diet associated

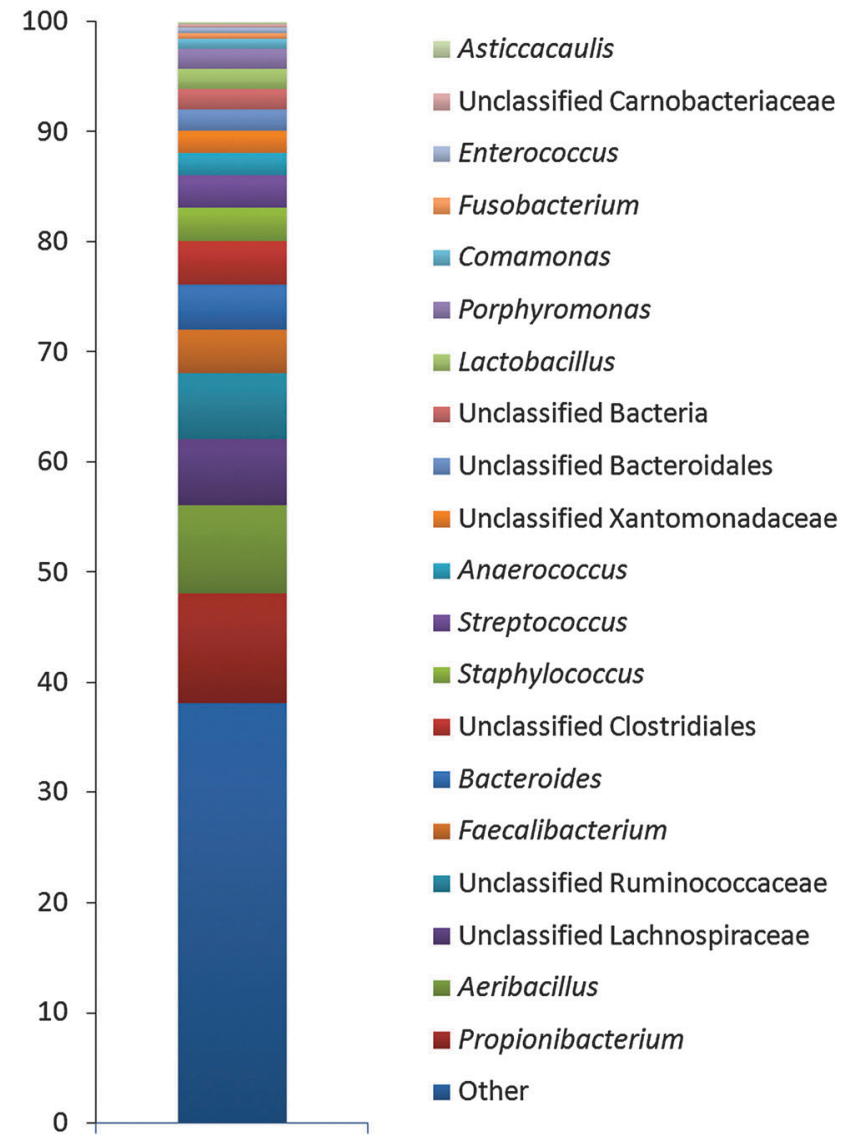

Fig. 2 Distribution of the twenty most prevalent bacterial genera found in 50 healthy quarter milk samples with less than 20000 cells $\mathrm{mL}^{-1.74}$

differences in milk microbial communities. In the work by Falentin et al. ${ }^{76}$ milk from healthy quarters was associated with a high proportion of the Clostridia class, the Bacteroidetes phylum and the Bifidobacteriales order. Table 2 summarizes the current findings on composition of the healthy cow milk microbiota.

Table 2 Composition of the healthy cow milk microbiota

\begin{tabular}{|c|c|}
\hline Study & Most prevalent genera \\
\hline Kuehn et $a l^{73}$ & $\begin{array}{l}\text { Ralstonia, Pseudomonas, Sphingomonas, } \\
\text { Stenotrophomonas, Psychrobacter, Bradyrhizobium, } \\
\text { Corynebacterium, Pelomonas, Staphylococcus }\end{array}$ \\
\hline Oikonomou et al. ${ }^{77}$ & $\begin{array}{l}\text { Propionibacterium, Aeribacillus, unclassified } \\
\text { Lachnospiraceae, Faecalibacterium, Bacteroides, } \\
\text { unclassified Clostridiales, Staphylococcus, } \\
\text { Streptococcus, Anaerococcus, unclassified } \\
\text { Xanthomonadaceae, unclassified Bacteroidales, } \\
\text { unclassified Bacteria, Lactobacillus, Porphyromonas, } \\
\text { Comamonas, Fusobacterium, Enterococcus, } \\
\text { unclassified Carnobacteriaceae, Asticcacaulis }\end{array}$ \\
\hline Zhang et al. ${ }^{75}$ & $\begin{array}{l}\text { Chryseobacterium, Streptococcus, Enterococcus, } \\
\text { Stenotrophomonas, Brevundimonas, Lactococcus, } \\
\text { Sphingomonas, Prevotella, Sphingobacterium, } \\
\text { Helcococcus, Leucobacter, Butyrivibrio, Atopostipes, } \\
\text { Bosea, Alcaligenes, Ruminococcus, Facklamia, } \\
\text { Actinomyces, Sphingobium, Trueperella, } \\
\text { Pseudomonas, Enterobacter, Comamonas, } \\
\text { Megasphaera, Salinicoccus, Ochrobactrum, } \\
\text { Lactobacillus, Mogibacterium, Peptococcus, } \\
\text { Succiniclasticum, Myroides }\end{array}$ \\
\hline
\end{tabular}


In dairy ruminant species other than cows, studies have been carried out almost exclusively for the purpose of dairy production, and not for investigating mammary health or offspring health. Therefore, experimental design and sampling procedures may not be adequate for extracting information on the sensu stricto milk microbiota. ${ }^{11}$

\section{Origin of the milk microbiota: the endogenous route hypothesis}

Traditionally, it is believed that bacteria found in milk result from contamination by the external environment, the mammary gland skin, or the oral cavity of the offspring. However, several studies support the hypothesis that the presence of bacteria in milk is not the mere result of external colonization. It has been demonstrated that, in addition to their different composition in terms of bacterial taxa, bacterial isolates present in the mammary gland are genotypically different from those found in skin, within the same host and the same bacterial species. ${ }^{78}$ Therefore, the udder skin and teat canal cannot be considered as the sole contributors to shaping the milk microbiota. ${ }^{65,79}$ In addition to this, bacteria such as bifidobacteria are strictly anaerobic, making skin an unlikely source. ${ }^{80}$ These and other observations have led to consider the possibility of an endogenous route. In fact, ecological niches in the host microbiota do not constitute separate environments, but are rather a network of inter-related communities undergoing constant exchanges. ${ }^{81}$ Therefore, microorganisms from other anatomical locations may in some way enter the mammary gland. More specifically, several authors described the existence of an entero-mammary pathway, based on the ability of some microbes to leave the intestinal lumen, travel through the mesenteric lymph nodes, and reach the mammary gland. ${ }^{65,71,78,82-85}$

The suggestion of an endogenous origin of the milk microbiota has been corroborated by different studies carried out in mice. ${ }^{71,86-89}$ Although the mechanisms by which microbes get to cross the intestinal barrier and reach other body sites have not been completely clarified, it is likely that these may involve immune cells, especially dendritic cells (DCs). ${ }^{71,82}$ In fact, DCs are able to sample intestinal contents by opening the tight junctions among enterocytes, and reach the lumen with their dendrites without damaging the epithelial barrier integrity. ${ }^{85,90}$ As a result of this sampling ability, these cells can harbor live commensal bacteria, and carry them to the mesenteric lymph nodes. ${ }^{91,92}$ Once there, bacteria remain viable for up to several days, and have the chance to spread to other distant mucosal surfaces, including the lactating mammary gland, by means of the mucosal associated lymphoid system. In fact, during lactation, cells from gut-associated lymphoid tissue travel to the breast via the lymphatic and peripheral blood circulations. Donnet-Hughes et al. showed that, during lactation, human peripheral blood mononuclear cells and breast milk cells contain bacteria and their genetic material. ${ }^{85}$ In addition, the presence of viable lactic acid bacteria in the bloodstream of human subjects has been reported, ${ }^{93-95}$ further showing that some members of the intestinal microbiota may have a rather underrated ability to travel to distant extra-intestinal locations of their host in a viable form. ${ }^{65}$ The authors also showed an increase in bacterial translocation from the mouse intestine during pregnancy and lactation and the presence of bacterially loaded DCs in lactating breast tissue.

The hormonal and physiological changes occurring during late pregnancy and lactation influence and condition permissivity of this bacterial transport. ${ }^{66}$ It is believed that, in addition to the transport of viable members of the intestinal microbiota, this mechanism has the role of educating the offspring's immune system to recognize molecular patterns associated with commensal microorganisms, in order to develop an appropriate response to them. ${ }^{85}$ This migration may occur either selectively, that is, certain strains may be recognized by immune cells and transported into milk, while others may not, or immune cells may take up all microorganisms, but only those able to escape killing would be transported to the mammary gland. ${ }^{96}$

A recent article by Young et al. reported the transfer of intestinal bacteria to the mammary gland in cows, supporting the existence of an endogenous entero-mammary pathway also in ruminants. ${ }^{97}$ The authors have investigated the microbial composition and diversity of feces, milk leukocytes and blood leukocytes in healthy lactating cows by pyrosequencing barcode-tagged 16S rDNA amplicons, demonstrating the shared presence of a small number of bacterial OTUs belonging to the Ruminococcus and Bifidobacterium genera and to the Peptostreptococcaceae family in all three samples from the same animals. In order to avoid external contamination and to prevent stretching or damaging of the teat canal, the authors used a catheter for collecting milk by gravity into a sterile container. The presence of these bacteria in the three environments supports the occurrence of a mechanism responsible for migration of some components of the intestinal microbiota to the mammary gland via circulating

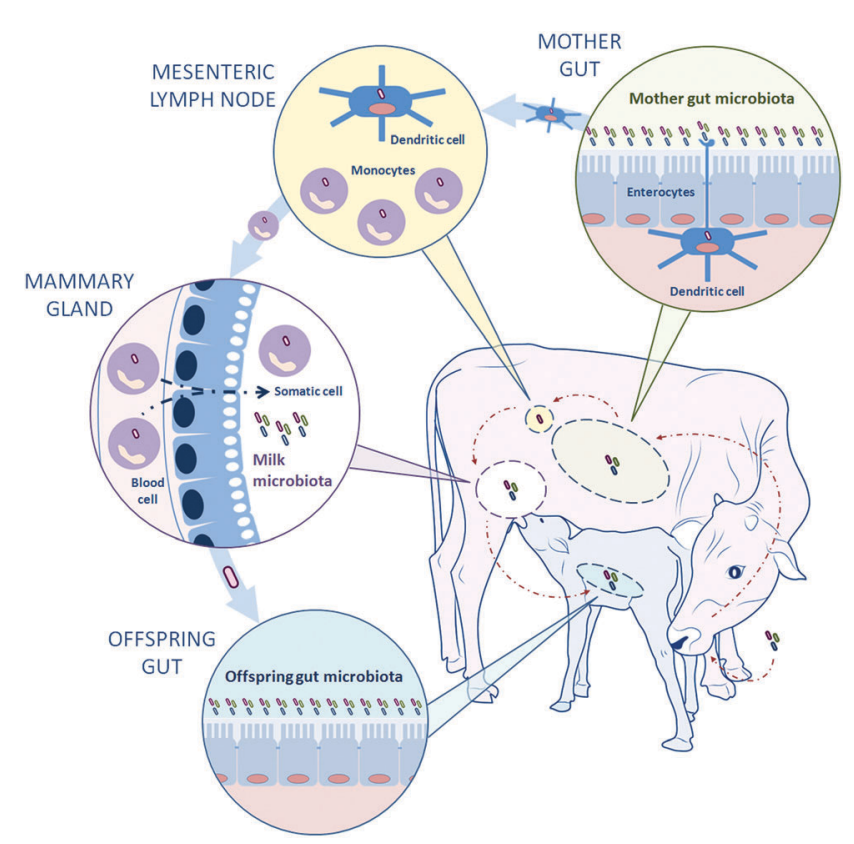

Fig. 3 Hypothesis of the entero-mammary pathway in ruminants and the mother-offspring microbial flow. 
white blood cells. However, the cell types responsible for the trafficking of microbiota from the mesenteric lymph nodes to milk remain to be established.

Further research will be needed to dissect the mechanisms by which intestinal bacteria are transported to the circulation and to the mammary gland of ruminants as well as to understand the implications that this can have for the health of the lactating animal, her offspring, and the human consumer. The current knowledge on the entero-mammary pathway hypothesis in ruminants is outlined in Fig. 3.

\section{Functions of the milk microbiota: lessons learned from human milk and the mouse model, and hints about its impact on the health of the ruminant offspring}

As stated above, most of the studies on the physiological milk microbiota of dairy ruminants have been carried out with focus on how the microbial flora of milk evolves when it ceases to become a sensu stricto biological fluid to become a processed food or a dairy product. ${ }^{11}$ Therefore, most of the insights into the physiology of the mother's milk microbiota and its influences on the offspring development and health have been gathered from studies on humans and on the mouse model.

The milk microbiota exerts many short and long term influences on the physiology of both the mother and the offspring. ${ }^{71,72,98-101}$ One of these is the transmission of microbes to the developing offspring's gastrointestinal tract (Fig. 3). ${ }^{65,78,80,102-104}$ The role of the milk microbiota as a "seed" for the developing intestinal microbiota is also evident in their close similarity; it is only after weaning that a significant diversification of the two communities takes place. ${ }^{105}$ As an example of the complex interaction among milk molecules, milk microbiota and offspring intestinal microbiota, it has been demonstrated that the abundant oligosaccharides present in human milk (HMOs, human milk oligosaccharides) are not digestible by the lactating infant. Instead, these are fermented by specific phylotypes of bifidobacteria and lactobacilli. ${ }^{106-109}$ In this way, HMOs provide a selective advantage to the milk and intestinal microbes that are able to metabolize them, and to thrive in the acidic environment generated by their digestion. In turn, this developing, selected microflora acts as a competitive "guard" to the blooming of adverse microbes. Although at a lower concentration than human milk, bovine milk does also contain complex milk oligosaccharides analogous to HMOs, the bovine milk oligosaccharides (BMOs). ${ }^{110-113}$ However, the role that these BMOs play in the milk microbiota of the cow mammary gland and of the intestinal microbiota has not been investigated yet.

Milk influences other health promoting bacteria, including Lactobacillus, Bacteroides, and Clostridium species, that can influence mucin production, mucosal permeability, T-cell balance, and dampening of mucosal inflammation. ${ }^{114-119}$ Studies carried out in germ-free mice have revealed that the development of a fully functional immune system requires early life colonization. ${ }^{120}$
All this considered, milk bacteria can be crucial for programming the appropriate functionality of the immune system against food antigens, pathogens, and commensal bacteria. Therefore, the intestinal microbiota of the offspring and the evolution of its immunity are shaped by the "seeding" operated by the milk microbiota derived from the mother's entero-mammary pathway, by the infant's environment, and by the continuous crosstalk between the mother's mammary gland and the suckling infant's oral microbiota, with their synchronized development and evolution throughout lactation. In support of this latter observation, Cabrera-Rubio et al. have demonstrated that the milk microbiota of healthy women evolves along lactation, and undergoes a series of changes as lactation proceeds. ${ }^{79}$

In ruminants, the role of the milk microbiota in shaping the intestinal microbiota of the newborn takes a further implication. In fact, these animals harbor an additional, very complex microbial community, the rumen microbiota, which has the crucial role of carrying out plant digestion and converting the otherwise non-digestible material into useful chemical compounds. ${ }^{121}$ Microbial colonization in the rumen occurs almost immediately; bacteria with cellulolytic capabilities are already present in 3-5 day old calves and are abundant in 2-3 week old calves. ${ }^{122,123}$ Recently, a study on ruminal bacterial communities has demonstrated that pre-ruminant calves harbor bacteria and functions that are present in mature animals. ${ }^{124}$ By using a pyrosequencing approach, Jami et al. have demonstrated that cellulolytic bacterial species are already present in the rumen of newborn calves as early as 1 day after birth and in increasing abundance on the third day. ${ }^{121}$ This is reinforced by Fonty et al. and Minato et al., who isolated cellulolytic bacteria from the rumen in the first week after birth. ${ }^{122,123}$ Jami et al. demonstrated that the establishment of crucial bacterial species in the rumen begins on the first day of life, when the animals are still being fed exclusively colostrum, that is, before the intake of the plant material. ${ }^{121}$ This notion has also been advanced for microbial communities in the developing human infant's intestinal microbiota. ${ }^{125}$ Although the authors have postulated that this primary bacterial community might be transmitted from the mother, they have proposed that this may occur via skin, the birth canal, or saliva. ${ }^{126}$ However, the role of the mother's entero-mammary pathway in seeding the microbiota of the young ruminant might deserve further investigation.

\section{The milk microbiota and mammary gland infection}

Mastitis due to intramammary infection is a highly prevalent disease in dairy cows and it is arguably the most important one for the dairy industry worldwide, causing economic losses due to reduced milk production, discarded milk, lower probability of conception, premature culling, and treatment cost. ${ }^{127}$ The decrease in milk production per cow resulting from mastitis has been well-studied, and is estimated to impact approximately $15 \%$ of the milk production potential of the affected cow. ${ }^{128}$ Mastitis is also a serious animal welfare issue as it is associated 
with pain, reduced well-being and behavioural changes of the affected animals. ${ }^{129}$ Defined as inflammation of the mammary tissue, it can be characterized by the movement of leukocytes and serum proteins from the blood to the site of infection. As a consequence, mastitis is typically monitored by using as an indicator the number of cells present in a milliliter of milk, defined as the somatic cell count, although novel, potentially highly sensitive, protein markers are emerging to aid its detection. ${ }^{130-137}$ Intramammary infection can be categorized into subclinical and clinical disease; the former is thought to be 3-40 times more prevalent than the latter and is defined as the presence of infection without clinical signs of local inflammation, whilst clinical mastitis involves an inflammatory response causing visibly abnormal milk, sometimes accompanied by swelling and/or redness of the mammary glands, and by an increase in the somatic cell count.

Identification of the bacteria responsible for intramammary infection is an important component of eventual clinical resolution of the disease. Currently, bacterial culture is the gold standard method for the identification of mastitis-causing microorganisms. However, limitations of classical bacterial culture, such as 48 hours to obtain results, or the fact that in approximately $25 \%$ of milk samples from clinical mastitis cases bacteria are not detected in conventional culture have spurred investigations of culture independent, molecular techniques for mastitis diagnosis. ${ }^{138}$ Methods such as real-time PCR, ${ }^{139}$ multiplex PCR (mPCR), ${ }^{140}$ denaturing gradient gel electrophoresis (DGGE) PCR, ${ }^{141}$ and PCR single-strand conformation polymorphism $(\mathrm{SSCP})^{142}$ are now being used to identify bacterial DNA in milk samples. Molecular epidemiological studies have greatly contributed in advancing our knowledge of bovine mastitis and have been extensively used for over two decades now. ${ }^{143}$

Bhatt et al. performed metagenomic analysis of milk samples collected from Kankrej, Gir (Bos indicus) and crossbred cattle affected with subclinical mastitis using shotgun sequencing and 454 GS-FLX technology. ${ }^{144}$ Their metagenomic approach confirmed the culturing results, but was also able to produce a significant amount of additional information. A total of 56 different species with varying abundance were detected in the subclinically infected milk together with several bacteriophages. The authors concluded that subclinical mastitis is a polymicrobial disease, a conclusion that was not well supported by their data mainly because samples from unaffected quarters were not obtained for comparison purposes.

Oikonomou et al. used metagenomic pyrosequencing of bacterial 16S rDNA genes to investigate bacterial DNA diversity in milk samples of mastitic and healthy dairy cows and compared the results with those obtained by classical bacterial culture. $^{145}$ One hundred and thirty-six milk samples were collected from cows showing signs of mastitis and used for microbiological culture. The mastitis pathogens identified by culture were generally among the most frequent organisms detected by pyrosequencing, and in some cases (Escherichia coli, Klebsiella spp. and Streptococcus uberis mastitis) the single most prevalent microorganism. Trueperella pyogenes sequences were the second most prevalent sequences in mastitis cases diagnosed as Trueperella pyogenes by culture, Streptococcus dysgalactiae sequences were the second most prevalent sequences in mastitis cases diagnosed as Streptococcus dysgalactiae by culture, and Staphylococcus aureus sequences were the third most prevalent in mastitis cases diagnosed as Staphylococcus aureus by culture. In samples that were aerobic culture negative, pyrosequencing identified DNA of bacteria that are known to cause mastitis, DNA of bacteria that are known pathogens but have so far not been associated with mastitis, and DNA of bacteria that are currently not known to be pathogens. Additionally, a high number of anaerobic bacterial sequences (with sequences belonging to Fusobacterium necrophorum being highly prevalent) were identified in all mastitis cases, regardless of the culturebased diagnosis. On the other hand, Fusobacterium necrophorum sequences were practically absent in the 20 samples that were derived from healthy, low somatic cell count quarters, while Porphyromonas spp. sequences were detected but in low prevalence compared to their prevalence in the mastitic samples. Therefore, a possible role of certain anaerobic bacteria as opportunistic pathogens was speculated. This study showed that the metagenomic pyrosequencing of 16S rDNA should be considered an important tool to advance our knowledge regarding the pathogenesis of bovine mastitis and could be developed as a diagnostic tool. However, being a cross-sectional prevalence study, it lacked the ability to show a proper time order to infer a cause and effect relationship. By using pyrosequencing of bacterial 16S rDNA genes, Kuehn et al. described the bacterial communities in culture negative mastitic milk samples, showing significant differences with healthy milk samples. Principal coordinates analysis suggested that non-clinical and clinical samples generally fell within separate clusters. ${ }^{73}$ In the study by Oikonomou et al., in addition to bacterial genera present in all the samples obtained from healthy quarters (Faecalibacterium, unclassified Lachnospiraceae, Propionibacterium and Aeribacillus), Streptococcus uberis sequences were found in all groups of samples, with a lower prevalence in low somatic cell counts groups. This was considered unexpected by the authors as this bacterial species is generally recognized as a major mastitis pathogen. It was hypothesized that Streptococcus uberis may, although in small quantities, be part of the normal milk microbiota, and therefore clinical mastitis may in such cases be a dysbiosis, rather than a simple primary infection. ${ }^{74}$ In the study by Falentin et al., quarters with a mastitis history showed a higher proportion of the Bacilli class (Staphylococcus) and Chlamydia class. ${ }^{76}$ Concerning dairy ruminant species other than cows, there are basically no -omics studies on how the milk microbiota changes in mastitis.

From the studies carried out in women on the role of the milk microbiota in intramammary infections and mastitis, we may gather useful hints on the possible role of the intestinal microbiota as a reservoir for mastitis-causing bacteria. On the other hand, mechanisms such as nutrient competition, bacteriocins and antimicrobial molecules released by specific members of the community in milk may play a role in repressing the blooming of potential pathogens, thereby preventing intramammary infections. ${ }^{100}$ Hunt and coworkers have reported the host-dependence of the milk microbiota in women, and have suggested that its composition may play a role in determining 
whether they will suffer or not from mastitis. ${ }^{72}$ As reviewed above, HMOs have the ability to modulate the intestinal microbiota of the breastfed infant, and structurally analogous oligosaccharides, BMOs, are present in cow milk. ${ }^{110-113}$ As such, it can be speculated that BMOs may also impact bacterial communities of the cow mammary gland. ${ }^{66}$ Interestingly, HMOs fall within milk group categories that mirror blood group characteristics, and are under genetic control. ${ }^{146}$ It has been demonstrated that some strains of Staphylococcus, the leading cause of mastitis in women, bind only to selected HMO types. ${ }^{147}$ This would suggest that susceptibility to mastitis might be conditioned not only by the bacterial composition of milk or by exposure to specific pathogens, but also by the genetic makeup of the animal and the corresponding type of BMOs present in milk. ${ }^{66}$

The existence of an entero-mammary pathway in ruminants ${ }^{97}$ (Fig. 3) opens several interesting speculations concerning possible alternative methods for mastitis treatment using antibiotics. In women, an effective mastitis treatment has been carried out by the oral administration of probiotics, including Lactobacillus salivarius CECT5713 and L. fermentum CECT5716. ${ }^{88,89}$ These impacted the milk microbiota by lowering the total bacterial count by $2 \log$ and replacing mastitis-causing Staphylococcus species with Lactobacillus species. This was also shown to facilitate breastfeeding, leading to health benefits for both the mother and the infant. The possibility of influencing the milk microbiota through the oral administration of pre- or probiotics may open interesting perspectives in reducing the risk of mastitis in dairy cows. ${ }^{148}$ These examples emphasize the possible magnitude of the milk microbiota influence on dairy ruminant health, demanding future investigations.

\section{The impact of farming practices on the mother/offspring microbiota crosstalk, and the waste milk issue}

Current farming practices pose several hindrances to the finely evolved crosstalk between the mother and the offspring microbiota. In fact, although calf management procedures can slightly vary among commercial dairy farms, ${ }^{149}$ calves are removed from their dams after birth, and administered colostrum, pooled colostrum, or colostrum substitutes. Then, they are typically fed whole bulk tank milk, milk replacer, or a combination of them, together with a starter feed. Therefore, the mother/offspring microbiota axis, with its reciprocal crosstalk, is disrupted. In ruminants that are left with their mothers, the mother/offspring crosstalk may play a relevant role in the evolution of both the mother's milk and the intestinal microbiota of the offspring along lactation.

In dairy calf management, attention should be paid to the quality of colostrum and milk that are administered in the farm, when considering that a healthy, well-balanced, microbiota-competent mother's milk is crucial for the correct development of the offspring's immune system. In fact, an imbalance in the intestinal microbiota is seen when calves are under stress conditions, such as in intensive rearing systems, with a reduction of Lactobacillus and Bifidobacterium species and an increase in pathobiont microorganisms. It is also interesting to notice that feeding whole milk to calves improved the ratio of lactic acid bacteria to coliforms, further demonstrating the complex action exerted by milk on the intestinal microbiota. ${ }^{150}$

Much care is taken to provide clean and high quality colostrum to newborn calves within 6 hours of birth. However, numerous farms use unsaleable, waste milk, for post-colostrum calf feeding. Waste milk is represented by milk which cannot be sold for human consumption, and it is typically derived from cows with high somatic cell counts and from cows treated with antibiotics. ${ }^{151}$ Feeding waste milk to preweaned calves is a widespread phenomenon, if one considers that, in 2002, it was practiced in $87.2 \%$ of all US dairy farms. ${ }^{152}$ The use of waste milk is economically advantageous for the farmer, and it is generally believed to be a safe and better alternative to milk replacers, especially after pasteurization. However, it can raise some concerns. In fact, waste milk can be heavily unbalanced in terms of milk microbiota, contaminated with potentially harmful pathogens, ${ }^{153}$ or contain antibiotic residues, with possible consequences on the future animal well-being. ${ }^{154}$

These issues have been examined by different research groups. Edrington et al. evaluated the effect of feeding waste milk on the bacterial diversity of the dairy calf fecal microbiota. ${ }^{149}$ The authors applied 16S rDNA bacterial tag-encoded FLX amplicon pyrosequencing to fecal samples from one week to six month old dairy calves fed pasteurized or unpasteurized waste milk. As a result, bacterial diversity in terms of the total number of different species was higher in calves fed pasteurized waste milk, and increased with age in both groups. Concerning specific microorganisms, Salmonella was detected in calves fed unpasteurized waste milk, and Treponema, an important beneficial bacterium in rumen, was higher in the pasteurized waste milk group, becoming higher with age in the same group. The consistent detection of Salmonella only in young calves fed unpasteurized waste milk was an important finding related to this practice. In conclusion, therefore, pasteurization of waste milk was advised. The impact of feeding bulk milk or waste milk on calf performance and health was also evaluated by Aust and coworkers. According to these authors as well, pasteurized waste milk can be considered an acceptable feed. ${ }^{155}$

A more significant problem concerning the use of waste milk, however, may be represented by the presence of antimicrobial residues, and the potential enrichment in the antibiotic resistance gene (ARG) pool available for transfer to pathogens, the "resistome". ${ }^{156}$ In addition, continuous antibiotic pressure may increase opportunities for horizontal ARG transfer. ${ }^{157-159}$ It should also be considered that the intestinal microbiota resistome is largely studied using culture-based or PCR-based experiments, with a consequent underestimation of novel resistance genes. ${ }^{160-163}$

An important aspect that needs to be taken into account when examining literature data is the administration route. In this respect, mouse models can provide useful indications for the impact of antibiotics fed to young calves through waste milk consumption, since in the case of infant mice antibiotics are administered through the mother's milk. ${ }^{154,164}$ In support 
of this observation, significant differences were observed upon oral administration versus intravenous administration of ampicillin and tetracycline. Oral administration resulted in a 4-log increase in ampicillin and a 2-fold increase in tetracycline resistance gene copy number over intravenous administration. This is also probably due to the fact that intravenously administered ampicillin is cleared through urine and does not interact with the gut microbiota. ${ }^{165}$

In addition to enrichment and selection of ARGs, antibiotics can affect specific phylogenetic subgroups of the intestinal microbiota. Preterm human infants treated with different antibiotics have an increased load of potentially pathogenic (pathobionts) Enterobacteriaceae, and a lower number of Bifidobacteriaceae, Bacilli, and Lactobacillales that are connected to a healthy microbiota. ${ }^{166-168}$ In mice exposed to subtherapeutic doses of antibiotics in drinking water, there was a significant decrease in the ratio of Bacteroides to Firmicutes, although this may depend on the specific spectrum of antibiotics used. ${ }^{164}$ In another study, the administration of cefoperazone was associated with a loss in microbial diversity without recovery at six weeks. ${ }^{169}$ Therefore, in mice, even low antibiotic dosages have long-term consequences on microorganisms associated with healthy microbiota, including Lactobacillus spp., Bifidobacteriaceae (lowered) and Enterobacteriaceae (increased). ${ }^{164,167}$

Limited information is currently available on the impact of drug residues on the microbiota using in vivo natural models. Van Vleck Pereira et al. evaluated the effect on the calf fecal microbiota of feeding raw milk spiked with antibiotic concentrations below the safe levels limit established by the Federal Department of Agriculture (FDA). ${ }^{170}$ Sequencing of the microbial 16S rRNA genes was conducted using the Illumina MiSeq on calf feces collected along six weeks of age. The study demonstrated that the presence of drug residues in the milk affects the composition of the microbial population in the feces. In fact, the weekly fecal microbial profile of the two calf groups was easily discriminated at the genus level, although no significant differences were seen for higher taxonomic levels. The authors postulated that even minimal antibiotic concentrations may have a selective impact on the competition among microbes, by influencing the final balance between sensitive and resistant microbial populations, that is, residues can exert a selective pressure on immature microbiota that have none or very low resistance to colonization by foreign microbes, resulting in an abrupt transition to a microbial profile that is most commonly found in older preweaned calves. In fact, when microbes are exposed to sub-minimal inhibitory concentrations of antibiotics, these will not kill all susceptible bacteria, but will impair their growth, providing a selective advantage to microbes that carry ARG with low fitness costs, contributing to their persistence even when the antibiotics are removed. ${ }^{171}$

The occurrence of changes in the fecal microbiota of young calves upon parenteral antibiotic administration was also seen by Oultram et al. in a preliminary study. ${ }^{172}$ One week post treatment the groups showed the greatest difference in the fecal microbiota composition, while two weeks post-treatment they became more similar, showing a recovery of microbial diversity in the treated group. Lactobacillus species were the most affected by antibiosis. Further studies will be needed, and are advised, to clarify the impact of antibiotic residues in milk on the correct maturation and health of the dairy ruminant microbiota.

Another farming practice potentially interfering with the milk microbiota balance is represented by the intramammary antibiotic therapy administered to cows at drying-off or during lactation. In fact, many dairy herds are routinely treated in every quarter with antibiotic at drying off. This is defined as the "blanket" approach, and is considered more effective than selective treatment in preventing new infections early in the dry period, without requiring laboratory screening procedures to decide which cows and quarters to treat. Lactation intramammary antibiotic tubes are the most common treatment for mild and moderate cases of mastitis, and are usually given without knowing the type of bacteria that is causing the infection. ${ }^{173,174}$ However, when subclinical mastitis in a herd is very low (every cow has an SCC below 100000 cells $\mathrm{mL}^{-1}$ ), intramammary antibiotic administration only to selected higher risk cows is considered appropriate by some dairy farmers and veterinarians. Because of concerns about selection for antimicrobial resistance, the blanket approach has not been implemented in the Nordic European countries for decades and it is increasingly abandoned in The Netherlands. The impact of this practice on the physiological milk microbiota and on the potential selection for ARG may deserve further investigation.

\section{Raw milk microbial ecology and its impact on dairy products}

Being a rich and nutritious fluid, milk supports the growth of many microorganisms. Therefore, in addition to its endogenous microbiota, once milked it is rapidly colonized by a variety of other microbes coming from the teat canal, udder skin, milking machines, containers and tanks used for its storage, reflecting the farm and the pasture environment as well. In addition to their contribution to milk fermentation by transforming lactose in lactate, they can bring about a variety of attributes that impact the sensory and textural characteristics of the dairy products derived from milk. ${ }^{175}$ Furthermore, contamination with, and subsequent growth of potentially pathogenic bacteria (or with toxins produced by them) in milk can have implications for human health and are therefore relevant issues to consider. And, it is also important to assess how the composition of the microbiota evolves in raw milk during milking, transport, storage, and dairy processing, and how it impacts the composition and quality of dairy products (Table 3).

These studies have been recently covered in a complete and extensive review by Quigley and coworkers, and we refer the readers to their work for a detailed description of the recent literature on this subject. ${ }^{11}$ In their review, the authors have described the current knowledge on the microorganisms that can be found in raw milk of the main dairy ruminant species. 
Table 3 Sources and impact of exogenous microorganisms found in raw milk ${ }^{11}$

\begin{tabular}{lllll}
\hline & Impact & & & \\
\cline { 2 - 5 } Sources & Food technology & Health promotion & Spoilage & Human illness \\
\hline Udder and teat & Lactococcus & Lactococcus & Pseudomonas & Listeria \\
Hides & Lactobacillus & Lactobacillus & Acinetobacter & Staphylococcus \\
Feces & Streptococcus & Streptococcus & Clostridium & Escherichia \\
Housing & Leuconostoc & Leuconostoc & Phages & Fycobacterium \\
Bedding & Enterococcus & Enterococcus & & Fungi - aflatoxins \\
Feed/pasture & Propionibacterium & Yeast species & & \\
Air & & & & \\
Water & & & &
\end{tabular}

\section{Conclusion}

The tremendous evolution of molecular and -omics technologies has enabled numerous breakthroughs in the study of microbial communities, making us aware of the varied and complex assortments of microbes that inhabit living animals and the reciprocal interactions that these entertain among themselves and with their hosts. Following the unexpected acknowledgement that even the healthy mammary gland and the milk contained within it are colonized by a variety of microbes, -omics approaches have already been used to enable their characterization in humans as well as to understand the role they play in the health of both the mother and the offspring. Following the studies on raw milk microbial ecology, -omics approaches are now beginning to be applied also to the sensu stricto milk microbiota of dairy ruminants. As a result, its relevant interactions with the physiology and health of the lactating dam and the suckling offspring are becoming more and more evident. Considering the significant economical implications that this can have for dairy ruminant farming, the application of -omics sciences to the milk microbiota is expected to improve our understanding of open questions and challenges, such as the etiology and dynamics of sub-clinical and culture-negative mastitis, the impact of farming management decisions on the health of the mammary gland and the offspring, the role of the intestine as a mastitis pathogen reservoir, the development of novel strategies for preventing and managing mastitis, and the control of antibiotic resistance.

\section{Acknowledgements}

The authors wish to thank Valeria Manghina for her useful suggestions on the manuscript.

\section{References}

1 J. Walter and R. Ley, Annu. Rev. Microbiol., 2011, 65, 411-429.

2 L. V. Hooper, D. R. Littman and A. J. Macpherson, Science, 2012, 336, 1268-1273.

3 M. Hamady and R. Knight, Genome Res., 2009, 19, 1141-1152.

4 D. C. Savage, Annu. Rev. Microbiol., 2003, 31, 107-133.

5 S. R. Gill, M. Pop, R. T. Deboy, P. B. Eckburg, P. J. Turnbaugh, B. S. Samuel, J. I. Gordon, D. A. Relman, C. M. Fraser-Liggett and K. E. Nelson, Science, 2006, 312, 1355-1359.
6 R. Sender, S. Fuchs and R. Milo, Revised estimates for the number of human and bacteria cells in the body, Cold Spring Harbor Labs Journals, 2016.

7 B. Cao, M. J. Stout, I. Lee and I. U. Mysorekar, Neoreviews, 2014, 15, e537-e545.

8 G. Mor and J.-Y. Kwon, Am. J. Obstet. Gynecol., 2015, 213, S131-S137.

9 A. Tolle, Bull. Int. Dairy Fed., 1980, 120, 4.

10 L. Hood, Science, 2012, 336, 1209.

11 L. Quigley, O. O'Sullivan, C. Stanton, T. P. Beresford, R. P. Ross, G. F. Fitzgerald and P. D. Cotter, FEMS Microbiol. Rev., 2013, 37, 664-698.

12 The Human Microbiome Project Consortium, Nature, 2012, 486, 207-214.

13 R. Lamendella, N. VerBerkmoes and J. K. Jansson, Curr. Opin. Biotechnol., 2012, 23, 491-500.

14 J. Kuczynski, C. L. Lauber, W. A. Walters, L. W. Parfrey, J. C. Clemente, D. Gevers and R. Knight, Nat. Rev. Genet., 2012, 13, 47-58.

15 H. Ji, D. W. Greening, E. A. Kapp, R. L. Moritz and R. J. Simpson, Proteomics: Clin. Appl., 2009, 3, 433-451.

16 T. J. Sharpton, S. J. Riesenfeld, S. W. Kembel, J. Ladau, J. P. O'Dwyer, J. L. Green, J. A. Eisen and K. S. Pollard, PLoS Comput. Biol., 2011, 7, e1001061.

17 T. J. Sharpton, Front. Plant Sci., 2014, 5, 209.

18 R. Logares, S. Sunagawa, G. Salazar, F. M. Cornejo-Castillo, I. Ferrera, H. Sarmento, P. Hingamp, H. Ogata, C. de Vargas, G. Lima-Mendez, J. Raes, J. Poulain, O. Jaillon, P. Wincker, S. Kandels-Lewis, E. Karsenti, P. Bork and S. G. Acinas, Environ. Microbiol., 2013, 16, 2659-2671.

19 Jumpstart Consortium Human Microbiome Project Data Generation Working Group, PLoS One, 2012, 7, e39315.

20 Z. Liu, T. Z. DeSantis, G. L. Andersen and R. Knight, Nucleic Acids Res., 2008, 36, e120.

21 P. D. Schloss, PLoS Comput. Biol., 2010, 6, e1000844.

22 M. G. I. Langille, J. Zaneveld, J. G. Caporaso, D. McDonald, D. Knights, J. A. Reyes, J. C. Clemente, D. E. Burkepile, R. L. Vega Thurber, R. Knight, R. G. Beiko and C. Huttenhower, Nat. Biotechnol., 2013, 31, 814-821.

23 S. G. Acinas, L. A. Marcelino, V. Klepac-Ceraj and M. F. Polz, J. Bacteriol., 2004, 186, 2629-2635.

24 E. A. Franzosa, X. C. Morgan, N. Segata, L. Waldron, J. Reyes, A. M. Earl, G. Giannoukos, M. R. Boylan, D. Ciulla, D. Gevers, 
J. Izard, W. S. Garrett, A. T. Chan and C. Huttenhower, Proc. Natl. Acad. Sci. U. S. A., 2014, 111, E2329-E2338.

25 A. Godzik, Curr. Opin. Struct. Biol., 2011, 21, 398-403.

26 X. C. Morgan, T. L. Tickle, H. Sokol, D. Gevers, K. L. Devaney, D. V. Ward, J. A. Reyes, S. A. Shah, N. LeLeiko, S. B. Snapper, A. Bousvaros, J. Korzenik, B. E. Sands, R. J. Xavier and C. Huttenhower, Genome Biol., 2012, 13, R79.

27 N. L. Yozwiak, P. Skewes-Cox, M. D. Stenglein, A. Balmaseda, E. Harris and J. L. DeRisi, PLoS Neglected Trop. Dis., 2012, 6, e1485.

28 K. C. Wrighton, B. C. Thomas, I. Sharon, C. S. Miller, C. J. Castelle, N. C. VerBerkmoes, M. J. Wilkins, R. L. Hettich, M. S. Lipton, K. H. Williams, P. E. Long and J. F. Banfield, Science, 2012, 337, 1661-1665.

29 S. Deusch, B. Tilocca, A. Camarinha-Silva and J. Seifert, Comput. Struct. Biotechnol. J., 2015, 13, 55-63.

30 D. R. Mende, A. S. Waller, S. Sunagawa, A. I. Järvelin, M. M. Chan, M. Arumugam, J. Raes and P. Bork, PLoS One, 2012, 7, e31386.

31 N. Delmotte, C. Knief, S. Chaffron, G. Innerebner, B. Roschitzki, R. Schlapbach, C. von Mering and J. A. Vorholt, Proc. Natl. Acad. Sci. U. S. A., 2009, 106, 16428-16433.

32 R. Schmieder and R. Edwards, Bioinformatics, 2011, 27, 863-864.

33 M. Garcia-Garcerà, K. Garcia-Etxebarria, M. Coscollà, A. Latorre and F. Calafell, PLoS One, 2013, 8, e74914.

34 M. Kim, K.-H. Lee, S.-W. Yoon, B.-S. Kim, J. Chun and H. Yi, Genomics Inform., 2013, 11, 102-113.

35 L. Cui, A. Morris and E. Ghedin, Genome Med., 2013, 5, 63.

36 A. K. Bartram, M. D. J. Lynch, J. C. Stearns, G. MorenoHagelsieb and J. D. Neufeld, Appl. Environ. Microbiol., 2011, 77, 3846-3852.

37 J. G. Caporaso, C. L. Lauber, W. A. Walters, D. Berg-Lyons, J. Huntley, N. Fierer, S. M. Owens, J. Betley, L. Fraser, M. Bauer, N. Gormley, J. A. Gilbert, G. Smith and R. Knight, ISME J., 2012, 6, 1621-1624.

38 A. S. Whiteley, S. Jenkins, I. Waite, N. Kresoje, H. Payne, B. Mullan, R. Allcock and A. O'Donnell, J. Microbiol. Methods, 2012, 91, 80-88.

39 W. Masoud, F. K. Vogensen, S. Lillevang, W. Abu Al-Soud, S. J. Sørensen and M. Jakobsen, Int. J. Food Microbiol., 2012, 153, 192-202.

40 L. Quigley, O. O'Sullivan, T. P. Beresford, R. P. Ross, G. F. Fitzgerald and P. D. Cotter, Int. J. Food Microbiol., 2011, 150, 81-94.

41 W. Masoud, M. Takamiya, F. K. Vogensen, S. Lillevang, W. A. Al-Soud, S. J. Sørensen and M. Jakobsen, Int. Dairy J., 2011, 21, 142-148.

42 E. A. Franzosa, T. Hsu, A. Sirota-Madi, A. Shafquat, G. Abu-Ali, X. C. Morgan and C. Huttenhower, Nat. Rev. Microbiol., 2015, 13, 360-372.

43 M. Valles-Colomer, Y. Darzi, S. Vieira-Silva, G. Falony, J. Raes and M. Joossens, J. Crohn's Colitis, 2016, 024.

44 A. T. Tveit, T. Urich and M. M. Svenning, Appl. Environ. Microbiol., 2014, 80, 5761-5772.

45 R. Sorek and P. Cossart, Nat. Rev. Genet., 2010, 11, 9-16.
46 S. He, O. Wurtzel, K. Singh, J. L. Froula, S. Yilmaz, S. G. Tringe, Z. Wang, F. Chen, E. A. Lindquist, R. Sorek and P. Hugenholtz, Nat. Methods, 2010, 7, 807-812.

47 H. Yi, Y.-J. Cho, S. Won, J.-E. Lee, H. Jin Yu, S. Kim, G. P. Schroth, S. Luo and J. Chun, Nucleic Acids Res., 2011, 39, e140.

48 J. Frias-Lopez, Y. Shi, G. W. Tyson, M. L. Coleman, S. C. Schuster, S. W. Chisholm and E. F. Delong, Proc. Natl. Acad. Sci. U. S. A., 2008, 105, 3805-3810.

49 M. J. Gosalbes, A. Durban, M. Pignatelli, J. J. Abellan, N. Jimenez-Hernandez, A. E. Perez-Cobas, A. Latorre and A. Moya, PLoS One, 2011, 6, e17447.

50 G. Giannoukos, D. M. Ciulla, K. Huang, B. J. Haas, J. Izard, J. Z. Levin, J. Livny, A. M. Earl, D. Gevers, D. V. Ward, C. Nusbaum, B. W. Birren and A. Gnirke, Genome Biol., 2012, 13, R23.

51 F. Abram, Comput. Struct. Biotechnol. J., 2015, 13, 24-32.

52 C. H. Ahrens, E. Brunner, E. Qeli and K. Basler, Nat. Rev. Mol. Cell Biol., 2010, 11, 789-801.

53 R. L. Hettich, C. Pan, K. Chourey and R. J. Giannone, Anal. Chem., 2013, 85, 4203-4214.

54 L. Mao and J. Franke, Proteomics, 2015, 15, 1142-1151.

55 C. A. Kolmeder and W. M. de Vos, J. Proteomics, 2013, 97, 3-16.

56 T. Muth, D. Benndorf, U. Reichl, E. Rapp and L. Martens, Mol. BioSyst., 2013, 9, 578-585.

57 A. Tanca, A. Palomba, M. Deligios, T. Cubeddu, C. Fraumene, G. Biosa, D. Pagnozzi, M. F. Addis and S. Uzzau, PLoS One, 2013, 8, e82981.

58 R. L. Hettich, R. Sharma, K. Chourey and R. J. Giannone, Curr. Opin. Microbiol., 2012, 15, 373-380.

59 A. Tanca, A. Palomba, S. Pisanu, M. Deligios, C. Fraumene, V. Manghina, D. Pagnozzi, M. F. Addis and S. Uzzau, Microbiome, 2014, 2, 1-16.

60 G. Winter and J. O. Kromer, Environ. Microbiol., 2013, 15, 1901-1916.

61 J. H. Faber, D. Malmodin, H. Toft, A. D. Maher, D. Crockford, E. Holmes, J. K. Nicholson, M. E. Dumas and D. Baunsgaard, J. Diabetes Sci. Technol., 2007, 1, 549-557.

62 A. Scalbert, L. Brennan, O. Fiehn, T. Hankemeier, B. S. Kristal, B. van Ommen, E. Pujos-Guillot, E. Verheij, D. Wishart and S. Wopereis, Metabolomics, 2009, 5, 435-458.

63 J. Tang, Curr. Genomics, 2011, 12, 391-403.

64 W. Xiong, P. E. Abraham, Z. Li, C. Pan and R. L. Hettich, Proteomics, 2015, 15, 3424-3438.

65 L. Fernández, S. Langa, V. Martín, A. Maldonado, E. Jiménez, R. Martín and J. M. Rodríguez, Pharmacol. Res., 2013, 69, 1-10.

66 P. V. Jeurink, J. van Bergenhenegouwen, E. Jiménez, L. M. J. Knippels, L. Fernández, J. Garssen, J. Knol, J. M. Rodríguez and R. Martín, Benefic. Microbes, 2013, 4, 17-30.

67 A. L. Morrow and J. M. Rangel, Semin. Pediatr. Infect. Dis., 2004, 15, 221-228.

68 G. Boehm and G. Moro, J. Nutr., 2008, 138, 1818S-1828S.

69 I. A. Penttila, J. Pediatr., 2010, 156, S21-S25.

70 A. Walker, J. Pediatr., 2010, 156, S3-S7. 
71 P. F. Perez, J. Doré, M. Leclerc, F. Levenez, J. Benyacoub, P. Serrant, I. Segura-Roggero, E. J. Schiffrin and A. DonnetHughes, Pediatrics, 2007, 119, e724-e732.

72 K. M. Hunt, J. A. Foster, L. J. Forney, U. M. E. Schutte, D. L. Beck, Z. Abdo, L. K. Fox, J. E. Williams, M. K. McGuire and M. A. McGuire, PLoS One, 2011, 6, e21313.

73 J. S. Kuehn, P. J. Gorden, D. Munro, R. Rong, Q. Dong, P. J. Plummer, C. Wang and G. J. Phillips, PLoS One, 2013, 8, e61959.

74 G. Oikonomou, M. L. Bicalho, E. Meira, R. E. Rossi, C. Foditsch, V. S. Machado, A. G. V. Teixeira, C. Santisteban, Y. H. Schukken and R. C. Bicalho, PLoS One, 2014, 9, e85904.

75 R. Zhang, W. Huo, W. Zhu and S. Mao, J. Sci. Food Agric., 2015, 95, 1072-1079.

76 H. Falentin, L. Rault, A. Nicolas, D. S. Bouchard, J. Lassalas, P. Lamberton, J.-M. Aubry, P.-G. Marnet, Y. Le Loir and S. Even, Front. Microbiol., 2016, 7, 480.

77 G. Oikonomou, M. L. Bicalho, E. Meira, R. E. Rossi, C. Foditsch, V. S. Machado, A. G. V. Teixeira, C. Santisteban, Y. H. Schukken and R. C. Bicalho, PLoS One, 2014, 9, e85904.

78 R. Martín, S. Langa, C. Reviriego, E. Jimínez, M. L. Marín, J. Xaus, L. Fernández and J. M. Rodríguez, J. Pediatr., 2003, 143, 754-758.

79 R. Cabrera-Rubio, M. C. Collado, K. Laitinen, S. Salminen, E. Isolauri and A. Mira, Am. J. Clin. Nutr., 2012, 96, 544-551.

80 M. Gueimonde, K. Laitinen, S. Salminen and E. Isolauri, Neonatology, 2007, 92, 64-66.

81 E. K. Costello, C. L. Lauber, M. Hamady, N. Fierer, J. I. Gordon and R. Knight, Science, 2009, 326, 1694-1697.

82 R. Martín, S. Langa, C. Reviriego, E. Jiménez, M. L. Marín, M. Olivares, J. Boza, J. Jiménez, L. Fernández, J. Xaus and J. M. Rodríguez, Trends Food Sci. Technol., 2004, 15, 121-127.

83 T. Jost, C. Lacroix, C. P. Braegger, F. Rochat and C. Chassard, Environ. Microbiol., 2014, 16, 2891-2904.

84 J. M. Rodríguez, Adv. Nutr., 2014, 5, 779-784.

85 A. Donnet-Hughes, P. F. Perez, J. Doré, M. Leclerc, F. Levenez, J. Benyacoub, P. Serrant, I. Segura-Roggero and E. J. Schiffrin, Proc. Nutr. Soc., 2010, 69, 407-415.

86 S. Langa, A. Maldonado-Barragán, S. Delgado, R. Martín, V. Martín, E. Jiménez, J. L. Ruíz-Barba, B. Mayo, R. I. Connor, J. E. Suárez and J. M. Rodríguez, Appl. Microbiol. Biotechnol., 2012, 94, 1279-1287.

87 M. Rescigno, S. Citterio, C. Thèry, M. Rittig, D. Medaglini, G. Pozzi, S. Amigorena and P. Ricciardi-Castagnoli, Proc. Natl. Acad. Sci. U. S. A., 1998, 95, 5229-5234.

88 E. Jiménez, L. Fernández, A. Maldonado, R. Martín, M. Olivares, J. Xaus and J. M. Rodríguez, Appl. Environ. Microbiol., 2008, 74, 4650-4655.

89 R. Arroyo, V. Martín, A. Maldonado, E. Jiménez, L. Fernández and J. M. Rodríguez, Clin. Infect. Dis., 2010, 50, 1551-1558.

90 M. Rescigno, M. Urbano, B. Valzasina, M. Francolini, G. Rotta, R. Bonasio, F. Granucci, J. P. Kraehenbuhl and P. Ricciardi-Castagnoli, Nat. Immunol., 2001, 2, 361-367.

91 A. Vazquez-Torres, J. Jones-Carson, A. J. Bäumler, S. Falkow, R. Valdivia, W. Brown, M. Le, R. Berggren, W. T. Parks and F. C. Fang, Nature, 1999, 401, 804-808.
92 A. J. Macpherson and T. Uhr, Science, 2004, 303, 1662-1665. 93 V. V. Vankerckhoven, T. Van Autgaerden, G. Huys, M. Vancanneyt, J. Swings and H. Goossens, Microb. Ecol. Health Dis., 2009, 16, 131-136.

94 A. C. Ouwehand, M. Saxelin and S. Salminen, Clin. Infect. Dis., 2004, 39, 1858-1860.

95 E. Jiménez, L. Fernández, M. L. Marín, R. Martín, J. M. Odriozola, C. Nueno-Palop, A. Narbad, M. Olivares, J. Xaus and J. M. Rodríguez, Curr. Microbiol., 2005, 51, 270-274.

96 P. D. Smith, T. T. MacDonald and R. S. Blumberg, Principles of Mucosal Immunology, Garland Science, 2012.

97 W. Young, B. C. Hine, O. A. M. Wallace, M. Callaghan and R. Bibiloni, PeerJ, 2015, 3, e888.

98 S. S. Beasley and P. E. J. Saris, Appl. Environ. Microbiol., 2004, 70, 5051-5053.

99 M. C. Collado, K. Laitinen, S. Salminen and E. Isolauri, Pediatr. Res., 2012, 72, 77-85.

100 M. P. Heikkilä and P. E. J. Saris, J. Appl. Microbiol., 2003, 95, 471-478.

101 M. E. Baldassarre, L. Bellantuono, P. Mastromarino, A. Miccheli, M. Fanelli and N. Laforgia, Curr. Pediatr. Rep., 2014, 2, 218-226.

102 Y. Matsumiya, N. Kato, K. Watanabe and H. Kato, J. Infect. Chemother., 2002, 8, 43-49.

103 H. Makino, A. Kushiro, E. Ishikawa, D. Muylaert, H. Kubota, T. Sakai, K. Oishi, R. Martin, K. Ben Amor, R. Oozeer, J. Knol and R. Tanaka, Appl. Environ. Microbiol., 2011, 77, 6788-6793.

104 S. Rautava, R. Luoto, S. Salminen and E. Isolauri, Nat. Rev. Gastroenterol. Hepatol., 2012, 9, 565-576.

105 G. Oikonomou, A. G. V. Teixeira, C. Foditsch, M. L. Bicalho, V. S. Machado and R. C. Bicalho, PLoS One, 2013, 8, e63157.

106 A. M. Zivkovic, J. B. German, C. B. Lebrilla and D. A. Mills, Proc. Natl. Acad. Sci. U. S. A., 2011, 108(suppl.), 4653-4658.

107 R. E. Ward, M. Niñonuevo, D. A. Mills, C. B. Lebrilla and J. B. German, Appl. Environ. Microbiol., 2006, 72, 4497-4499.

108 D. A. Sela, J. Chapman, A. Adeuya, J. H. Kim, F. Chen, T. R. Whitehead, A. Lapidus, D. S. Rokhsar, C. B. Lebrilla, J. B. German, N. P. Price, P. M. Richardson and D. A. Mills, Proc. Natl. Acad. Sci. U. S. A., 2008, 105, 18964-18969.

109 F. Turroni, F. Bottacini, E. Foroni, I. Mulder, J.-H. Kim, A. Zomer, B. Sánchez, A. Bidossi, A. Ferrarini, V. Giubellini, M. Delledonne, B. Henrissat, P. Coutinho, M. Oggioni, G. F. Fitzgerald, D. Mills, A. Margolles, D. Kelly, D. van Sinderen and M. Ventura, Proc. Natl. Acad. Sci. U. S. A., 2010, 107, 19514-19519.

110 A. M. Zivkovic and D. Barile, Adv. Nutr., 2011, 2, 284-289. 111 T. Urashima, E. Taufik, K. Fukuda and S. Asakuma, Biosci., Biotechnol., Biochem., 2013, 77, 455-466.

112 D. L. Aldredge, M. R. Geronimo, S. Hua, C. C. Nwosu, C. B. Lebrilla and D. Barile, Glycobiology, 2013, 23, 664-676.

113 R. Mehra, D. Barile, M. Marotta, C. B. Lebrilla, C. Chu and J. B. German, PLoS One, 2014, 9, e96040.

114 W. A. Walker and R. S. Iyengar, Pediatr. Res., 2015, 77, 220-228.

115 D. A. Hill and D. Artis, Annu. Rev. Immunol., 2010, 28, 623-667. 
116 M. J. Barnes and F. Powrie, Science, 2011, 331, 289-290.

117 A. Frey, K. T. Giannasca, R. Weltzin, P. J. Giannasca, H. Reggio, W. I. Lencer and M. R. Neutra, J. Exp. Med., 1996, 184, 1045-1059.

118 C. U. Duerr and M. W. Hornef, Semin. Immunol., 2012, 24, 25-35.

119 M. B. Geuking, J. Cahenzli, M. A. E. Lawson, D. C. K. Ng, E. Slack, S. Hapfelmeier, K. D. McCoy and A. J. Macpherson, Immunity, 2011, 34, 794-806.

120 K. Smith, K. D. McCoy and A. J. Macpherson, Semin. Immunol., 2007, 19, 59-69.

121 E. Jami, A. Israel, A. Kotser and I. Mizrahi, ISME J., 2013, 7, 1069-1079.

122 G. Fonty, P. Gouet, J.-P. Jouany and J. Senaud, Microbiology, 1987, 133, 1835-1843.

123 H. Minato, M. Otsuka, S. Shirasaka, H. Itabashi and M. Mitsumori, J. Gen. Appl. Microbiol., 1992, 38, 447-456.

124 R. W. Li, E. E. Connor, C. Li, R. L. Baldwin Vi and M. E. Sparks, Environ. Microbiol., 2012, 14, 129-139.

125 J. E. Koenig, A. Spor, N. Scalfone, A. D. Fricker, J. Stombaugh, R. Knight, L. T. Angenent and R. E. Ley, Proc. Natl. Acad. Sci. U. S. A., 2011, 108(suppl.), 4578-4585.

126 M. G. Dominguez-Bello, E. K. Costello, M. Contreras, M. Magris, G. Hidalgo, N. Fierer and R. Knight, Proc. Natl. Acad. Sci. U. S. A., 2010, 107, 11971-11975.

127 J. A. Hertl, Y. T. Gröhn, J. D. G. Leach, D. Bar, G. J. Bennett, R. N. González, B. J. Rauch, F. L. Welcome, L. W. Tauer and Y. H. Schukken, J. Dairy Sci., 2010, 93, 1551-1560.

128 Y. H. Schukken, J. Hertl, D. Bar, G. J. Bennett, R. N. González, B. J. Rauch, C. Santisteban, H. F. Schulte, L. Tauer, F. L. Welcome and Y. T. Gröhn, J. Dairy Sci., 2009, 92, 3091-3105.

129 C. Medrano-Galarza, J. Gibbons, S. Wagner, A. M. de Passillé and J. Rushen, J. Dairy Sci., 2012, 95, 6994-7002.

130 M. Akerstedt, L. Forsbäck, T. Larsen and K. SvennerstenSjaunja, J. Dairy Res., 2011, 78, 88-96.

131 F. Ceciliani, J. J. Ceron, P. D. Eckersall and H. Sauerwein, J. Proteomics, 2012, 75, 4207-4231.

132 T. T. Wheeler, G. A. Smolenski, D. P. Harris, S. K. Gupta, B. J. Haigh, M. K. Broadhurst, A. J. Molenaar and K. Stelwagen, Animal, 2012, 6, 415-422.

133 F. C. Thomas, M. Waterston, P. Hastie, T. Parkin, H. Haining and P. D. Eckersall, BMC Vet. Res., 2015, 11, 207.

134 M. F. Addis, S. Pisanu, S. Ghisaura, D. Pagnozzi, G. Marogna, A. Tanca, G. Biosa, C. Cacciotto, A. Alberti, M. Pittau, T. Roggio and S. Uzzau, Infect. Immun., 2011, 79, 3833-3845.

135 M. F. Addis, S. Pisanu, G. Marogna, T. Cubeddu, D. Pagnozzi, C. Cacciotto, F. Campesi, G. Schianchi, S. Rocca and S. Uzzau, Infect. Immun., 2013, 81, 3182-3197.

136 S. Pisanu, T. Cubeddu, D. Pagnozzi, S. Rocca, C. Cacciotto, A. Alberti, G. Marogna, S. Uzzau and M. F. Addis, Vet. Res., 2015, 46, 59.

137 M. F. Addis, V. Tedde, S. Dore, S. Pisanu, G. M. G. Puggioni, A. M. Roggio, D. Pagnozzi, S. Lollai, E. A. Cannas and S. Uzzau, J. Dairy Sci., 2016, DOI: 10.3168/jds.2015-10293.

138 S. Taponen, L. Salmikivi, H. Simojoki, M. T. Koskinen and S. Pyörälä, J. Dairy Sci., 2009, 92, 2610-2617.
139 M. T. Koskinen, G. J. Wellenberg, O. C. Sampimon, J. Holopainen, A. Rothkamp, L. Salmikivi, W. A. van Haeringen, T. J. G. M. Lam and S. Pyörälä, J. Dairy Sci., 2010, 93, 5707-5715.

140 B. R. Shome, S. Das Mitra, M. Bhuvana, N. Krithiga, D. Velu, R. Shome, S. Isloor, S. B. Barbuddhe and H. Rahman, J. Appl. Microbiol., 2011, 111, 1349-1356.

141 Y. Kuang, K. Tani, A. J. Synnott, K. Ohshima, H. Higuchi, H. Nagahata and Y. Tanji, Biochem. Eng. J., 2009, 45, 76-81.

142 K. Schwaiger, M. Wimmer, R. Huber-Schlenstedt, K. Fehlings, C. S. Hölzel and J. Bauer, J. Dairy Sci., 2012, 95, 98-101.

143 R. N. Zadoks, J. R. Middleton, S. McDougall, J. Katholm and Y. H. Schukken, J. Mammary Gland Biol. Neoplasia, 2011, 16, 357-372.

144 V. D. Bhatt, V. B. Ahir, P. G. Koringa, S. J. Jakhesara, D. N. Rank, D. S. Nauriyal, A. P. Kunjadia and C. G. Joshi, J. Appl. Microbiol., 2012, 112, 639-650.

145 G. Oikonomou, V. S. Machado, C. Santisteban, Y. H. Schukken and R. C. Bicalho, PLoS One, 2012, 7, e47671.

146 S. Thurl, M. Munzert, J. Henker, G. Boehm, B. Müller-Werner, J. Jelinek and B. Stahl, Br. J. Nutr., 2010, 104, 1261-1271.

147 J. A. Lane, R. K. Mehra, S. D. Carrington and R. M. Hickey, Anal. Biochem., 2011, 410, 200-205.

148 C. Ma, J. Zhao, X. Xi, J. Ding, H. Wang, H. Zhang and L. Y. Kwok, Benefic. Microbes, 2015, 1-8.

149 T. S. Edrington, S. E. Dowd, R. F. Farrow, G. R. Hagevoort, T. R. Callaway, R. C. Anderson and D. J. Nisbet, J. Dairy Sci., 2012, 95, 4519-4525.

150 M. L. Signorini, L. P. Soto, M. V. Zbrun, G. J. Sequeira, M. R. Rosmini and L. S. Frizzo, Res. Vet. Sci., 2012, 93, 250-258.

151 J. R. Chardavoyne, J. A. Ibeawuchi, E. M. Kesler and K. M. Borland, J. Dairy Sci., 1979, 62, 1285-1289.

152 USDA, Dairy 2007, Part IV: Reference of Dairy Cattle Health and Management Practices in the United States, Fort Collins, CO, 2007.

153 H. W. Barkema, M. J. Green, A. J. Bradley and R. N. Zadoks, J. Dairy Sci., 2009, 92, 4717-4729.

154 L. M. Cox, S. Yamanishi, J. Sohn, A. V. Alekseyenko, J. M. Leung, I. Cho, S. G. Kim, H. Li, Z. Gao, D. Mahana, J. G. Zárate Rodriguez, A. B. Rogers, N. Robine, P. Loke and M. J. Blaser, Cell, 2014, 158, 705-721.

155 V. Aust, K. Knappstein, H. J. Kunz, H. Kaspar, J. Wallmann and M. Kaske, J. Anim. Physiol. Anim. Nutr., 2013, 97, 1091-1103.

156 M. O. A. Sommer, G. M. Church and G. Dantas, Virulence, 2010, 1, 299-303.

157 C. S. Smillie, M. B. Smith, J. Friedman, O. X. Cordero, L. A. David and E. J. Alm, Nature, 2011, 480, 241-244.

158 B. Stecher, R. Denzler, L. Maier, F. Bernet, M. J. Sanders, D. J. Pickard, M. Barthel, A. M. Westendorf, K. A. Krogfelt, A. W. Walker, M. Ackermann, U. Dobrindt, N. R. Thomson and W.-D. Hardt, Proc. Natl. Acad. Sci. U. S. A., 2012, 109, 1269-1274.

159 N. Karami, A. Martner, V. I. Enne, S. Swerkersson, I. Adlerberth and A. E. Wold, J. Antimicrob. Chemother., 2007, 60, 1142-1145. 
160 S. R. Modi, J. J. Collins and D. A. Relman, J. Clin. Invest., 2014, 124, 4212-4218.

161 H. E. Jakobsson, C. Jernberg, A. F. Andersson, M. SjölundKarlsson, J. K. Jansson and L. Engstrand, PLoS One, 2010, 5, e9836.

162 S. Löfmark, C. Jernberg, J. K. Jansson and C. Edlund, J. Antimicrob. Chemother., 2006, 58, 1160-1167.

163 C. Jernberg, S. Löfmark, C. Edlund and J. K. Jansson, Microbiology, 2010, 156, 3216-3223.

164 I. Cho, S. Yamanishi, L. Cox, B. A. Methé, J. Zavadil, K. Li, Z. Gao, D. Mahana, K. Raju, I. Teitler, H. Li, A. V. Alekseyenko and M. J. Blaser, Nature, 2012, 488, 621-626.

165 L. Zhang, Y. Huang, Y. Zhou, T. Buckley and H. H. Wang, Antimicrob. Agents Chemother., 2013, 57, 3659-3666.

166 C. Greenwood, A. L. Morrow, A. J. Lagomarcino, M. Altaye, D. H. Taft, Z. Yu, D. S. Newburg, D. V. Ward and K. R. Schibler, J. Pediatr., 2014, 165, 23-29.

167 S. Tanaka, T. Kobayashi, P. Songjinda, A. Tateyama, M. Tsubouchi, C. Kiyohara, T. Shirakawa, K. Sonomoto and J. Nakayama, FEMS Immunol. Med. Microbiol., 2009, 56, 80-87.
168 S. Arboleya, B. Sánchez, C. Milani, S. Duranti, G. Solís, N. Fernández, C. G. de los Reyes-Gavilán, M. Ventura, A. Margolles and M. Gueimonde, J. Pediatr., 2015, 166, 538-544.

169 D. A. Antonopoulos, S. M. Huse, H. G. Morrison, T. M. Schmidt, M. L. Sogin and V. B. Young, Infect. Immun., 2009, 77, 2367-2375.

170 R. Van Vleck Pereira, S. Lima, J. D. Siler, C. Foditsch, L. D. Warnick and R. C. Bicalho, PLoS One, 2016, 11, e0147525.

171 L. Sandegren, Upsala J. Med. Sci., 2014, 119, 103-107.

172 J. Oultram, E. Phipps, A. G. V. Teixeira, C. Foditsch, M. L. Bicalho, V. S. Machado, R. C. Bicalho and G. Oikonomou, Vet. Rec., 2015, 103320.

173 F. G. H. Hoe and P. L. Ruegg, J. Dairy Sci., 2006, 89, 2297-2308.

174 L. Oliveira and P. L. Ruegg, J. Dairy Sci., 2014, 97, 5426-5436.

175 J. T. M. Wouters, E. H. E. Ayad, J. Hugenholtz and G. Smit, Int. Dairy J., 2002, 12, 91-109. 